\title{
Fertőző összeesküvés-elméletek A koronavírus körüli konteók mint mémek
}

\section{A koronavírus-járvány}

2020 szeptemberében a Facebook közösségi oldal elkezdte sorban törölni a magyar vírustagadók, a koronavírussal kapcsolatban szkeptikus nézeteket hirdető (ál)szakemberek oldalait (Index 2020). A 2020 júliusában megjelent Karanténszótár (Veszelszki 2020a) azonban még nem tartalmazza a vírusszkeptikus, koronatagadó, maszkellenes kifejezéseket, mivel ez az attitüd és az ezt jellemző lexikai egységek nagy számban a szótár publikálása után jelentek meg. Az összeesküvés-elméletek, az úgynevezett konteók azonban már a vírusfertőzés terjedésével szinte egyszerre megszülettek (vö. koronakonteó).

Az új típusú betegség tudományos megismerése és az erről szóló (orvosi, szakmai) kommunikáció a hatékony megelőzés és kezelés érdekében közel egy időben zajlik: éppen ezért lehetséges, hogy a kutatók a legfrissebb eredmények függvényében új és új javaslatokkal állnak elő (lásd például az Egészségügyi Világszervezet, a WHO ajánlásainak változását a maszkviselés fontosságával kapcsolatban). A bizonytalan, szinte napról napra változó, nehezen kiszámítható helyzet ${ }^{1}$ összeesküvés-elméletek sorát hozta magával: egyesek úgynevezett plandémiáról, azaz megtervezett világjárványról is beszélnek, a fertőzés és annak következményei (a bezárkózás, annak társadalmi és gazdasági hatásai) mögött valamely nagyhatalom szándékos manipulációját sejt(et)ve.

A jelen cikk a koronavírus-járvánnyal kapcsolatos összeesküvés-elméletekkel foglalkozik két nézőpontból: egyrészt a konteókat mémként értelmezve, másrészt pedig az internetes mémekben megjelenő tartalomként.

\section{A konteók mint mémek}

\subsection{A kulturális epidemiológia és az összeesküvés-elméletek}

Hátborzongató a mémek terjedését a jelen szituációban éppen a kulturális epidemiológia elméletével magyarázni. Márpedig a kulturális jelenségek járványtani terjedésének elképzelése nem új keletű teória. A mém az eredeti mémelmélet szerint (Dawkins 1993) egy, a génekre hasonlító kulturális egység, amely „önző” replikátorként müködik: célja a terjedés, függetlenül attól, hogy igaz-e, és hogy az ezt továbbadó személy profitál-e belőle (Rizeq et al. 2020: 4). Dan Sperber (1996: 57, 100-1; Dawkins 1993 és Dennett 1990 nyomán) azt állítja, hogy az emberi elme fogékony a kulturális reprezentációk befogadására, akárcsak az emberi szervezet

1 A közbeszéd egyik jellemzőjévé vált (vö. Veszelszki 2020b, c), hogy egyre többen használják a magán- és a közéleti kommunikációban is (kognitív) metaforaként a háború forrástartományát a helyzet leírására (vö. a vírus elleni küzdelem, háborúban állunk, le kell gyöznünk a fenyegetést, együtt nyerni fogunk stb.). 
a betegségekre. Annak megértéséhez, miért terjednek a reprezentációk a társadalomban, a „kulturális epidemiológia” metaforáját hívja segítségül, két megkötéssel: egyrészt a kulturális reprezentációk a betegségterjesztő vírusokkal szemben nem patologikusak, nem kórosak, másrészt míg a hagyományos vírusok nem minden esetben mutálódnak a transzmisszió során, addig a reprezentációk a terjedésükkor szinte mindig megváltoznak, így sok variációjuk jön létre (Sperber 1996: 24-5, 58). A kulturális reprezentációk terjedhetnek nagyon lassan, generációról generációra (mint a hagyományok), illetve elérhetnek gyorsan egy nagyobb populációt (mint a divat vagy a pletyka, Sperber 1996: 58) - és ez a sor kiegészíthetö az összeesküvés-elméletekkel is.

Az összeesküvés-elméletek egy - összetartozó vagy összefüggés nélküli - eseménysort rendszerint jelentős befolyással bíró emberek rossz szándékú tevékenységéhez kötnek (vö. Tanács 2016). „A konspirációs teóriák fontos alkotóelemei [...] az ún. kóbor adatok, amelyek vagy ellentmondanak a hivatalos változatnak, vagy a hivatalos változat keretében, magyarázat nélkül hagyott egyéb" információk (Fehér-Király 2017: 43), amelyek egymástól távol eső, látszólag teljesen különálló eseményeket kapcsolnak össze. A konspirációs elméletek, az úgynevezett konteók további sajátossága, hogy ,az ellenük szóló bizonyítékokat a maguk előnyére tudják fordítani" (Fehér-Király 2017: 44). Valójában cáfolhatatlanok, mivel aszimmetrikusan kezelik az érvelésük mellett és az az ellen szóló bizonyítékokat: az alátámasztó bizonyítékokat minden további nélkül elfogadják, de az ellenük szólókról azt állítják, hogy azok éppenhogy félrevezetők, az elmélet tagadása révén megtévesztők, hamis szándékúak, vagy akár nem tudományosak (lásd Veszelszki-Falyuna 2019). Az összeesküvés-elméletek hitelességének látszatához hozzájárul az is, hogy nem izolált állításokat tesznek, hanem komplex (világnézet)rendszert dolgoznak ki.

Blancke és szerzőtársai (2018) az áltudományos nézetek és a velük rokon összeesküvés-elméletek terjedését is a Sperber-féle kulturális epidemiológia (1996) segítségével magyarázzák, és három fö okra vezetik vissza (vö. részletesen Veszelszki-Falyuna 2019; Veszelszki 2021). Ezek közül az első az intuitív vonzerő, miszerint azoknak a nézeteknek van legnagyobb esélyük a népszerüvé válásra, amelyek megfelelnek a nem tudatos, spontán elvárásainknak (Boyer-Barret 2005). Az áltudományok és a konteók is éppen ezekre a hiedelmekre képesek alapozni (Boudry et al. 2015), ezért könnyen megérthetők, megjegyezhetök és továbbadhatók, szemben egyes tudományos meglátásokkal, amelyek ellentmondanak az emberi megérzéseknek, és megértésük nagyobb kognitív erőfeszítést igényel (Blancke et al. 2017). Gelfert (2018: 111) megerősítési torzításként hivatkozik erre a jelenségre, amelyben az információfogyasztó azokat az új bizonyítékokat preferálja, amelyek alátámasztják a meglévő hiedelmeit, vélekedéseit.

A második ok a ,tudomány mimikrije”, azaz a tudomány módszertanának, nyelvhasználatának és intézményrendszerének az utánzása (Blancke et al. 2018; vö. a hitelesség látszata, Veszelszki 2017). A tudományos közeg hagyományosan kulturális presztízzsel rendelkező, megbízható információforrás, ezért az áltudományok számára „megéri” magukat tudományként reprezentálni. Mivel a tudomány nagy presztízzsel rendelkezik, de nem mindenki van tisztában a tudományosság kritériumaival, a magukat tudományosnak beállító nézetrendszerek a tudományosság utánzásával 
autoritást szereznek (vö. Falyuna 2017, 2018). Az összeesküvés-elméletek terjesztői a saját narratívájuk szerint valamilyen titkos tudásba avatják be a közönségüket (olvasóikat, hallgatóikat). Sperber et al. (2010) episztemikus éberségként nevezi meg azt a képességet, hogy a személy különbséget tud tenni megbízható és megbízhatatlan információ (bizalomra érdemes és hazug források) között. Az episztemikus éberség alapvetően két irányból müködik: egyrészt a forrást (megbízhatóságát, hírnevét, esetleges rejtett célját), másrészt a tartalmat (konzisztenciáját, más nézetekkel való koherenciáját) ellenőrzi. Ha müködik az első mechanizmus, vagyis az áltudományos nézet vagy összeesküvés-elmélet megfelel az ember intuícióinak, továbbá az áltudományok a tudomány könnyebben hozzáférhető, külső jellegzetességeit is magukon hordozzák, és megbízható forrásként tüntetik fel magukat, az csökkenti az éberséget.

A harmadik mechanizmus pedig a kritikára való immunitás. A kulturális epidemiológiai nézet (Blancke et al. 2018) szerint az áltudományos nézeteknek a túlélésük és terjedésük érdekében ellenállónak kell lenniük a racionális kritikával, az empirikus bizonyítékokkal szemben (vö. Boudry-Braeckman 2011, 2012).

Mindezek mellett segíti az összeesküvés-elméletek terjedését a közösségi média tartalomszürő algoritmusa is: ez határozza meg, hogy a böngészés során milyen információk kerülnek a fogyasztók elé. A Facebook EdgeRank algoritmusa több tényezö alapján elemzi a feltöltött tartalmakat, és tárja azokat a felhasználók elé a személyes nyitóoldalukon (Zimmer et al. 2019). Az affinitás jelöli a felhasználó korábbi, különböző szempontok szerint rangsorolt interakcióit (megtekintés, lájkolás, megosztás, komment), ezek súlyozva kerülnek a rangsorolásba. Az aktualitás is lényeges szerepet játszik: minél frissebb a tartalom, annál relevánsabbnak tekinti az algoritmus, de számít a felhasználók közötti földrajzi közelség is. A Facebook tartalomrankingje mögött rejlő algoritmust folyamatosan, a platform céljainak megfelelően, de a felhasználók számára nem transzparens módon optimalizálják. A tartalom-rangsorolás miatt lehetséges, hogy a felhasználók a hasonló érdeklődési körrel rendelkező, egymással gyakran interakcióba lépök tartalmaival találkoznak a legtöbbször. A filterbuborék ( $f i l$ ter bubble; vö. Pariser 2011; Vīḳe-Freiberga et al. 2013; Bakshy et al. 2015; Fehér 2016: 138, 157) hipotézise szerint, ha a felhasználó csak a saját nézeteinek megfelelö, azokat megerősítő tartalmakkal találkozik, akkor úgy vélheti, hogy mindenki hozzá hasonló módon gondolkodik. A közösségi médiában megjelenő információk perszonalizációja révén kialakuló filterbuborék egyfajta digitális hiedelemkamraként müködik: a közösségi oldalaknak az az érdekük, hogy a felhasználó minél több (hirdetések megnézésére is fordítható) idöt töltsön a felületükön, ezért a korábbi kereséseinek, preferenciáinak megfelelő tartalmakat szür és tár elé az algoritmus. Ezt erösíti továbbá, hogy nagy valószínűség szerint hasonló érdeklődési körrel, hiedelmekkel rendelkező személyek tartoznak egy ismerösi körbe. Söt a közösségi oldalakon a felhasználók egymás ismerete nélkül is tudnak csoportokat, közösségeket kialakítani: a hasonló nézeteket vallók könnyen ,egymásra találhatnak”, és igazolhatják, erősíthetik egymást a megalapozatlan, akár szélsőséges nézeteikben is (Falyuna 2018).

A legújabb vizsgálatok szerint a hírfogyasztók kisebb arányban fordulnak a tényellenőrző és -hitelesítő oldalakhoz, ha az információkkal a közösségi oldalakon 
találkoznak - még abban az esetben is, ha a hír megosztója nem is közvetlenül ismerősük. Mások jelenléte elaltatja éberségünket - állítják kísérletek alapján a kutatók (Jun et al. 2017), mivel ,a megbízható személyes ismerős adott esetben márkázott csatornának számít" (Szvetelszky 2017: 28). Érdemes azonban megjegyezni, hogy a filterbuborék jelenségét empirikus adatok alapján egyes kutatások megkérdőjelezik (pl. Zuiderveen Borgesius et al. 2016); ugyanakkor annyi mindenképpen állítható, hogy az online felületek mögött müködő algoritmusok befolyással bírnak arra, milyen információkkal találkozik a böngésző személy az interneten. Ha azonban nem fogadjuk el a filterbuborék-jelenség meglétét, abban az esetben is müködik az úgynevezett ismétlési hatás (Gelfert 2018: 112): ha ugyanazzal az információval többször, akár ugyanolyan forrásból, redundáns módon találkozik a felhasználó, az az ismétlés révén sokkal meggyőzőbb lesz számára. A kommentek is információismétlö, alátámasztó szerepet játszhatnak az áltudományos és konteójellegü tartalmak terjedésében és megerösítésében (Veszelszki 2017: 71; 2021; Falyuna 2018).

Stanovich (2009; Stanovich et al. 2008; Stanovich et al. 2016) ,szennyezett elmetartalomként" (contaminated mindware) utal azokra a hiedelmekre, amelyek a racionális gondolkodás ellen hatnak. Ezeknek az episztemikusan gyanús nézeteknek három fö területét jelöli ki: a paranormális hiedelmeket, az összeesküvés-elméleteket és a tudományellenes attitüdöt. Az episztemikus racionalitás azt jelenti, hogy az ember a döntéseit és cselekvéseit aszerint tervezi meg, hogy mit gondol igaznak a világról (Stanovich 2016) - az összeesküvés-elméletek és a rájuk épülő álhírek azonban a kritikus gondolkodás és racionális döntéshozatal ellen hatnak. A Stanovich (2009) által leírt „szennyezett elmetartalom” nem azért problematikus, mert egyesek információ hiányában nem tudnak megfelelő egyéni vagy a közösséget érintő döntéseket meghozni, hanem azért, mert a téves információk és ellenőrizetlen hiedelmek és attitüdök miatt képtelenek az alternatív megoldási lehetőségek mérlegelésére, a reflexív hozzáállásra (Rizeq et al. 2020: 2). Az összeesküvés-elméletek (ugyan gyakran van igazságtartalmuk) nem rendelkeznek bizonyítékokkal, és a cáfolattal szemben kifejezetten ellenállónak bizonyulnak (Sutton-Douglas 2014; Rizeq et al. 2020).

\subsection{Koronavírus-konteók: oltásellenesség, chipbeültetés, 5G}

A koronavírus-járvány és a megjelenésével szinte egy időben elkezdett oltáskísérletek új lendületet adtak az oltásellenes mozgalomnak (vö. Veszelszki-Falyuna 2020). Pedig a védőoltásokat megtagadók révén az utóbbi évtizedekben olyan betegségek is elkezdtek újra terjedni, amelyeket elvileg az emberiség már legyőzött. A közösségi médiában gyorsan híveket szerző, a félelemre apelláló és az összeesküvés-elméletekhez kötődő mozgalom áltudományos érvelésre, illetve nem megalapozott vizsgálati eredményeket közlő publikációkra épít.

Oltásellenes mozgalom azóta létezik, amióta elérhetővé váltak az oltások (Kirkpatrick é. n.). A gyengített kórokozóval történő oltásokkal számos, korábban legyőzhetetlennek tekintett fertőző betegség terjedését lehet megelőzni. Mivel a beoltott szervezetet ellenőrzött formában „megfertőzik” az adott betegséggel, ez óhatatlanul is bizalmatlanságot vált ki többekből (vö. Veszelszki-Falyuna 2019, 2020). 
E bizalmatlanság erősödéséhez hozzájárulnak olyan esetek, amikor az oltás valódi károkat okozott (például 1955-ben Kaliforniában gyengítetlen poliovírust adtak be a gyerekeknek, ennek következtében 40 ezren megbetegedtek járványos gyermekbénulásban, és 50-nél többen ténylegesen meg is bénultak).

Az oltások megtagadásához (McKenna 2019) a bizalom hiányán túl hozzájárulhatnak vallási megfontolások, illetve az interneten viharszerüen végigsöprő oltásellenes mozgalom is. Ennek egyik kiindulópontját egy brit kutató 1998-ban megjelent cikke adja, amelyben kétes módszertannal, csekély számú mintán, kontrollcsoport bevonása nélkül azt bizonyította be, hogy az MMR-oltás (measles, mumps, rubella) és az autizmus kialakulása között direkt ok-okozati összefüggés van. A,„20. század legkárosabb orvosi hoaxának" (Flaherty 2011) nevezett cikk állításait később tételesen cáfolták. Ám hiába vonatták vissza a manipulált adatokat tartalmazó, megalapozatlanul következtetéseket levonó cikket 2010-ben, addigra az (interneten is terjedö) oltásellenesség már széles teret nyert, egyre többen tagadták meg a gyermekük beoltását a tudományos csaláson alapuló tanulmány hatására. Ennek következtében jelentősen megnövekedett (többek között) a kanyarós és a mumpszos esetek száma, előbb Nagy-Britanniában, később szerte a világon. Ehhez hozzájárult az is, hogy ismert, véleményvezérnek számító személyek is a mozgalom mellé álltak, sőt legújabban még csetbotok és Twitter-trollok aktivitása is erősíti az oltásellenesség hatását (Broniatowski et al. 2018; Veszelszki-Falyuna 2019).

Az egyértelmű egészségügyi és financiális következményekkel járó áltudományos mozgalom egyik érveléstechnikai alapját az itt bemutatott intuitív vonzeró (Boyer-Barret 2005) adja. A kórokozóval való beoltás és az ehhez direkt módon kapcsolódó káros következmények ok-okozati összefüggése megfelel a nem tudatos elvárásoknak, ezért az érvelés nagyobb kognitív erőfeszítés nélkül megérthető, megjegyezhető és terjeszthető. Az esetükben a „tudomány mimikrijét” részint a kísérleti módszertanra való hivatkozás, részint pedig a laikus fogyasztók számára nehezen befogadható orvostudományi terminológia teremti meg (vö. Veszelszki-Falyuna 2019). Az oltásellenesek továbbá használják - az egyébként a politikai kommunikációban és a marketingben is gyakran alkalmazott - félelemre épító érvelést (valójában érvelési hibát; vö. argumentum in terrorem). A félelem, a pánik a bizonytalan járványügyi helyzetben minden további érvelés nélkül is kihasználható létállapot.

A 2020-as koronavírus-járvánnyal kapcsolatban az Egészségügyi Világszervezet az úgynevezett infodémia, vagyis a fertőzés témájában terjedő téves információk, álhírek, összeesküvés-elméletek megjelenésére figyelmeztetett (WHO 2020; Veszelszki 2020a; Vraga et al. 2020). Ebbe a körbe tartoznak az oltásellenesek mellett a vírustagadó, maszkszkeptikus attitüdök is. Összeesküvés-elméletek keringenek a vírus eredetével (miszerint laborban szándékosan elöállított, onnan biológiai fegyverként tudatosan elterjesztett kórokozó lenne), a fertőzés terjedésével és a lehetséges gyógymódokkal kapcsolatban is (Brennen et al. 2020).

Spring (2020) összegyüjtötte azt a hét típust, akik különböző motivációval hamis információkat terjesztenek a vírussal kapcsolatban a közösségi médiában. E rendszerezésben mutatom be az általam 2020 januárja és szeptembere között lejegyzett eseteket is (lásd 1-3. ábra is). 


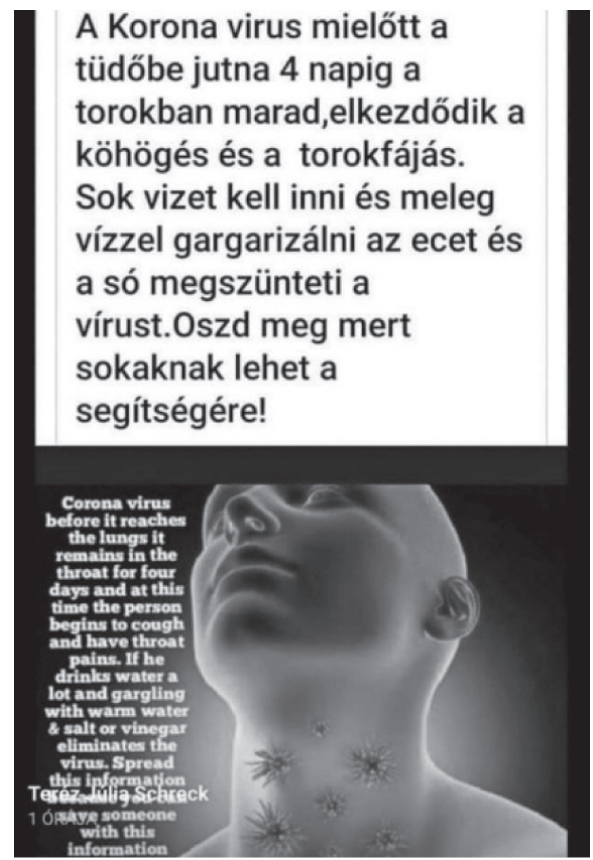

1. ábra. A vírusfertőzés elkerülésével kapcsolatos álhír
"A koronavirus margójára...

"A vírusok NAGYON ALACSONY REZGÉSÜEK, kb. 5,5 $\mathrm{Hz}$ és $14,5 \mathrm{~Hz}$ között. A magasabb tartományban nem aktívak, kb. 25,5 Hz-es rezgésen szétesnek. A magas rezgésü személyek számára nem veszélyesebb, mint egy súlyosabb légzőszervi fertőzés. Az emberi test akinek a lelke jó egészségben van, magasabban rezeg. Sajnos sok ember alacsonyabb érzelmi, hangulati szinten van, ami meghatározza a rezgését. Az okok: fáradtság, érzelmi kiégettség, krónikus betegségek, félelmek, elfojtott érzelmek, idegi feszültség, stb.

A vírus a természetben a testen kívül nem ellenálló, mivel az átlagos Föld frekvencia rezonancia ma kb. $27,4 \mathrm{~Hz}$. De vannak helyek, ahol ez a frekvencia alacsony tartományban van, kevesebb mint $20 \mathrm{~Hz}$, pl. kórházak, bevásárló központok, irodaházak, adótornyok közelében és elektroszmoggal súlyosan terhelt környezetben. Ez lehet akár egy szoba is mindenféle elektromos berendezéssel, sőt újabban a most bevezetésre kerülö $5 \mathrm{G}$ hálózat amely erösen életellenes sugárzás.

\begin{abstract}
Akik nem látnak ki az egojukból, életüket a félelem irányítja, ami rendkívül alacsony rezgésen tart, így a vírus rájuk nagyobb hatással lehet. A félelem hangulatában a rezgés $0,2-$ töl $2,2 \mathrm{~Hz}$, az aggodalom $0,6-3,3 \mathrm{~Hz}$ között tart, a mig például a nagylelküség $95 \mathrm{~Hz}$, a hála rezgése $140 \mathrm{~Hz}$. A feltétel nélküli egyetemes szeretet $205 \mathrm{~Hz}$-töl is magasabb.
\end{abstract}

2. ábra. A vírusfertőzés rezgéssel történő magyarázata, álhír

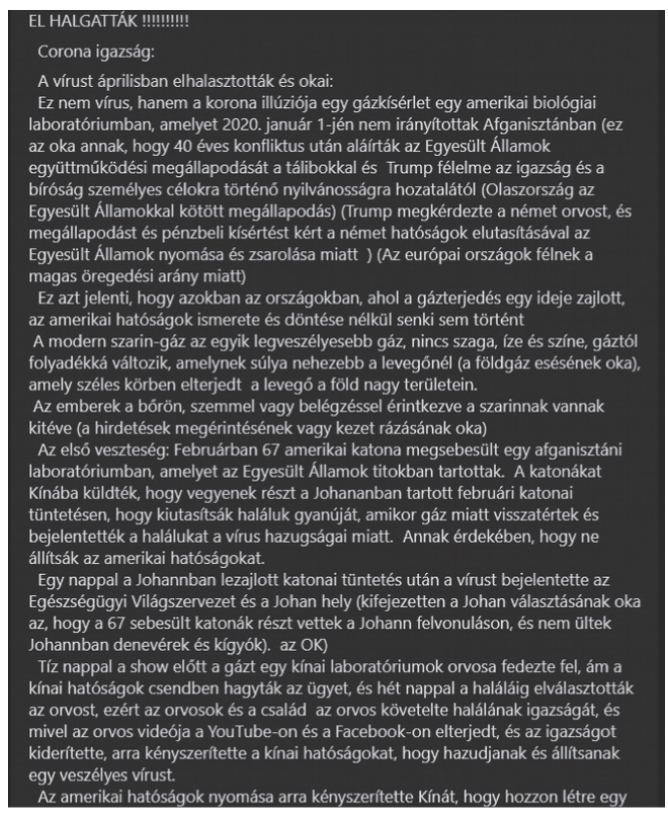

3. ábra. Komplex összeesküvés-elmélet a vírus eredetével kapcsolatban 
1. Csaló (scammer). Pénzügyi nyereségre akart szert tenni adatkinyerő csalással a járvány miatt az, aki azt terjesztette el, hogy a kormányzat fájdalomdíjat fizet a lakosoknak - cserébe csak a banki azonosítóikat kell megadniuk. Továbbá csaló e-mailekben vették rá a címzetteket arra, hogy hamis, adathalász oldalakra kattintsanak, azzal, hogy az adott linken megkaphatják a vírus ellenszerét vagy éppen a vírus miatti adó-visszatérítés szabályait. A pánikkeltés egyik motivációja az adott oldal látogatottságának, ezáltal a reklámbevételnek a növelése is lehet (Szicherle-Krekó 2020).

2. Összeesküvéselmélet-hívö (conspiracy theorist). Szicherle és Krekó (2020) a Magyarországon februárig megjelent konteókat négy csoportba sorolta: „népirtás-elméletek” (a gazdasági hatalomért vagy a túlnépesedés ellen, az úgynevezett Új Világrend érdekében); „,biológiai fegyver” (eszerint a vírust az így zajló harmadik világháborúban Kína ellen használják); „világvége” (az emberiség kihalását, az apokalipszist vizionálják); ,,az elkészült ellenszer” (2020 februárjában elterjedt a hír - még szeptemberben sincs meg a biztos gyógymód, 2020 decemberében kezdődtek meg az oltások; arra alkalmas volt viszont, hogy alternatív kezelési módokat eladjanak szélesebb közönségnek).

3. Jól informált (insider). Egy magát egészségügyi dolgozónak kiadó nő Angliában keltett pánikot azzal a virálisan terjedő hangüzenetével, miszerint egyébként egészséges fiatalok tömegesen halnak meg a kórházakban a fertőzéstől, ám ezt mindenki eltitkolja a nyilvánosság előtt; az üzenetről később kiderült, hogy teljes mértékben kitalált történet. Veszélyes valótlanságokat állító lánclevél terjedt februárban Egy olasz orvos a koronavirusról címmel (Molnár 2020), ebben szerepel sok más hamis információ mellett az is, hogy a vírust a meleg víz és a napfény elpusztítja, már 26-27 fokon ez nyilvánvalóan lehetetlen, hiszen az emberi szervezet 36-37 fokos. Ebbe a körbe tartozott az a magukat orvosnak kiadó posztolóktól származó valótlan információ is, miszerint ha negyedóránként vizet fogyasztunk, nem betegedhetünk meg, mert a vírus így a gyomorba kerül, ahol a gyomorsav elpusztítja (1. ábra). Egy ugyancsak alaptalan tanács szerint, ha reggelente tíz másodpercnél hosszabb ideig köhögés nélkül vissza tudjuk tartani a levegőt, akkor nem vagyunk fertőzöttek. Az ilyen tippek azért problémásak, mert hamis biztonságérzetet adnak, és esetlegesen tünetmentesen fertőzött személyek másokat is megfertőznek (Sáringer 2020).

4. Rokon (relative). A családjukért aggódó emberek tömegesen osztották meg a családtagjaikkal és ismerőseikkel a rémhíreket, „hátha mégis igaznak bizonyulnak"; kifejezetten segítő szándékkal.

5. Vicces (joker). Egy magát humorosnak gondoló férfi azt híresztelte, hogy a brit kormány óriási lasagnét készít a Wembley stadionban, hogy a járvány miatt éhező londoniakat étkeztessék; sokan nem értették a viccet, és az üzenet virálisan terjedt. Egy másik esetben azzal ijesztgették az embereket egy erről szóló hamis brit kormányzati iratról készült képernyőfelvétellel, hogy óriási büntetést kell azoknak fizetniük, akik a kijárási korlátozás alatt túl sokszor elhagyták az otthonukat - a Facebook-csoportokban terjedő üzenet valódi pánikot okozott Angliában. 
6. Politikus (politician). Sajnos a közösség hiteles tájékoztatásáért felelős politikusok is terjesztenek - különböző okokból, tudatlanságból, tájékozatlanságból vagy éppen szándékosan rémhírterjesztő, manipulatív céllal - hamis információkat, például hogy az UV-fény vagy a fertőtlenítőszer belsőleges fogyasztása gyógyítja a fertőzést; vagy hogy a vírust az amerikai hadsereg csempészte be a wuhani laborba.

7. Celeb (celebrity). Nemcsak hétköznapi emberek, ismerősök, hanem széles követői körrel rendelkező, ezáltal a nyilvánosságra nagy befolyással bíró emberek is megosztották az összeesküvés-elméleteket. Egy 2020. áprilisi kutatás (Brennen et al. 2020) szerint a top-down jellegü, azaz a politikusoktól, celebritásoktól vagy más közszereplőktől származó hamis információk a mintavételnek csupán 20\%-át tették ki, ám a közösségimédia-aktivitás 69\%-a ezekhez kapcsolódott. A hamis hírek nagy része hétköznapi emberektől származott, ám sokkal kisebb aktivitást váltott ki.

A vírushoz kapcsolódó konteók veszélye a fentieken kívül, hogy nyomukban az ezeket a nézeteket követők szembefordulnak a hivatalos intézkedésekkel, és megnehezítik az összefogást a járvány megfékezésében. A másik, konkrét veszélyt a téves gyógykezelések, egészen pontosan félrekezelések jelentik. Vannak ártalmatlan, bár hatástalan kúrák, mint a fokhagymafogyasztás vagy a varázserejü ásványok használata (BBC 2020). De elterjedt az az információ is, miszerint az alkohol megöli a vírust, erre többen is metil-alkoholt fogyasztottak, és megmérgezték magukat (FJ 2020); hasonlóképpen a kezdetben hatásos ellenszernek tartott klorokin is egészségre káros anyagnak bizonyult (Vraga et al. 2020).

Az oltásellenességnek új lendületet adott az az elképzelés, miszerint a koronavírus-fertőzés elleni oltással együtt a háttérhatalom (egyik megtestesítője a milliárdos Microsoft-alapító, az oltások fejlesztését nagy összegekkel támogató Bill Gates) mikrochipet akar ültetni az emberekbe, hogy ily módon kontrollálja a tömegeket (vö. Hanula 2020; Szicherle-Krekó 2020).

A világméretü járvány olyan mértékü félelmet váltott ki a lakosságban, hogy igen sokan a digitális technológiát kezdték el a vírus terjedéséért hibáztatni, és úgy gondolták, hogy a legújabb telekommunikációs hálózatfejlesztés, az $5 \mathrm{G}$ felelős a pandémiáért. Arra is magyarázatot adott ez a konspirációs elmélet, hogy azért a kínai Wuhanból terjedt el a világon a vírus, mert ott vezették be elsőként ezt az új mobiltechnológiát. Az 5G-ellenes konteó egyik következménye az lett, hogy egyfajta posztmodern luddita mozgalomként Nagy-Britanniában több csoport mobiltelefonállomás-rombolásba kezdett (Portfolio 2020; HVG 2020). ${ }^{2}$

\section{Koronakonteók a mémekben}

A koronavírussal kapcsolatos összeesküvés-elméleteknek az internetes mémek is egyfajta görbetükröt állítanak. Az internetes mém olyan jelenség, fogalom, szöveg,

2 2020. március és május vége között több mint 77 5G-tornyot rongáltak meg a technológia ellenzői az Egyesült Királyságban, és 180 esetben zaklatták a távközlési cégek munkatársait (HVG 2020). 
videó, kép vagy kép-szöveg kapcsolat, amely az interneten gyorsan és divatszerüen terjed; tartalma vicc, pletyka, motiváló üzenet, (ál)hír is lehet (Veszelszki 2013). $\mathrm{Az}$ internetes mémgyártás célja a legtöbbször valamely aktuális társadalmi-közéleti jelenség kigúnyolása. A mémeknek igen erőteljes közösségalkotó hatásuk van, ezáltal a felhasználók társadalmi, politikai mobilizálására is szolgálhatnak. A mémalkotók - anonim vagy a mémen a forrást megjelölve névhez kötött, személyes márkát építő - népszerüségre tehetnek szert, a szórakoztatás és a humor révén.

„A humor igen hatékony szabályozó eszköz lehet a kommunikációban, a metakommunikáció szerepét is betöltheti. [...] Viszonyszabályozó szerepe is lehet, hiszen negatív indulatokat old fel, közelítheti az embereket egymáshoz" (Buda 1986: 79). A humor fő funkcióit általában három nagy csoportba rendezik (vö. Mulkay 1988; Kuiper et al. 1993; Martin 2007): 1. a jókedély kognitív és szociális hasznai; 2. feszültségcsökkentés, problémakezelés; 3 . társadalmi kommunikáció és befolyás. E jellegzetességei (indulatfeloldó és problémakezelő, embereket közelítő hatása) miatt lehet hatékony a humor a fizikai és lelki nehézségekkel való megküzdésben, mint amilyen a járványhelyzet és következményei (betegség és attól való félelem, egzisztenciális szorongás, megváltozott élet- és munkakörülmények stb.). Egy korábbi helyzetjelentésben (Veszelszki 2020c) bemutattam a karanténnal kapcsolatos mémeket; itt kifejezetten a koronakonteók mémlenyomataiból mutatok jellemző példákat (4-9. ábra).

A (külsőleg, fertőtlenítő- és tisztítószerként alkalmazott) alkohol elpusztítja a vírust - ám többen ezt úgy értelmezték, hogy a több alkoholos ital fogyasztása megvéd a fertözéstől; ezt összekapcsolja a hírhedten sok alkoholt fogyasztó kelet-európaiak sztereotípiájával (4. ábra). Az 5., 6. és 7. ábra mémje arra a konteóra reflektál, miszerint az $5 \mathrm{G}$ terjesztené a fertőzést. A 8. és 9 . ábra a jelenleg keringő áltudományos nézeteket mutatja be ironikus formában.

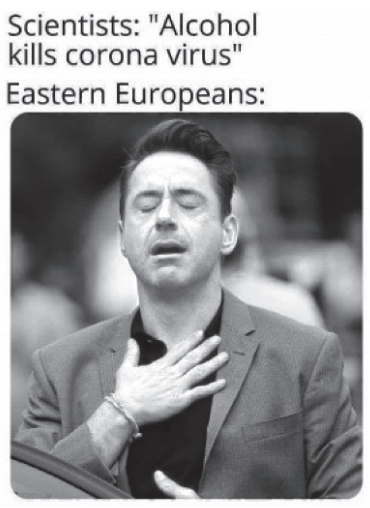

4. ábra. „Tudósok: »Az alkohol megöli a koronavírust« Kelet-európaiak:"

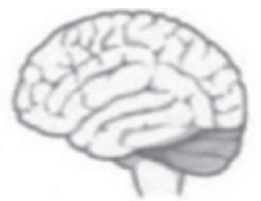

Brain of a human.

\section{Brain of a cat.}

Brain of someone

who thinks 5G

Brain of a rat

causes Coronavirus

5. ábra. „Emberi agy. Macskaagy. Patkányagy. Annak az agya, aki azt hiszi, az 5G okozza a koronavírust" 


\section{When the $5 \mathrm{G}$ towers give you COVID-19 and you begin emitting your own WiFi.}

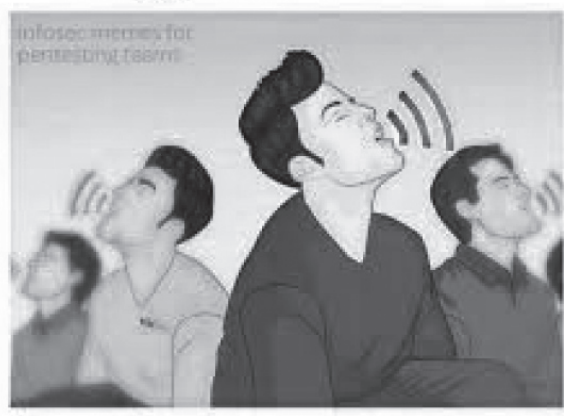

6. ábra. „Ha az 5G-töl el lehet kapni a covid19-et, és wifit kezdesz kibocsátani”

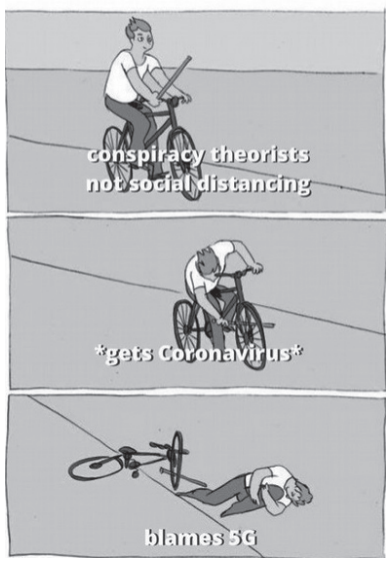

7. ábra. „Konteóhívő nem tartja be a társas távolságtartást. Elkapja a koronavírust. Az 5G-t hibáztatja”

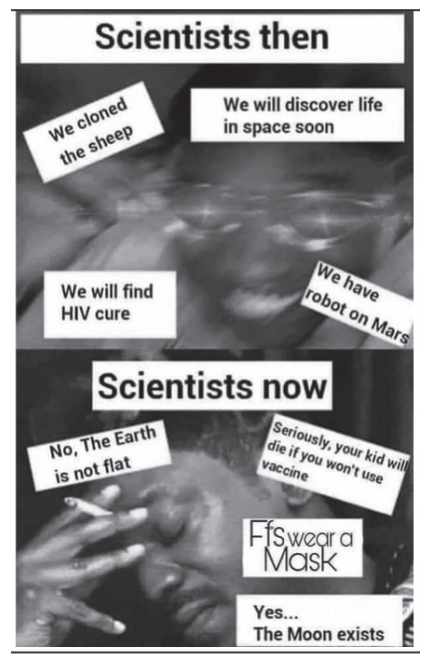

8. ábra. ,Tudósok régebben: »Birkát klónoztunk«, »Hamarosan felfedezzük az életet az ürben«, »Megtaláljuk a HIV gyógymódját«, »Robotot küldtünk a Marsra«.” „Tudósok most: »A Föld nem lapos«, »Komolyan, a gyerek meghal, ha nem oltják be«, »Hordjunk maszkot« »Igen, a Hold létezik«

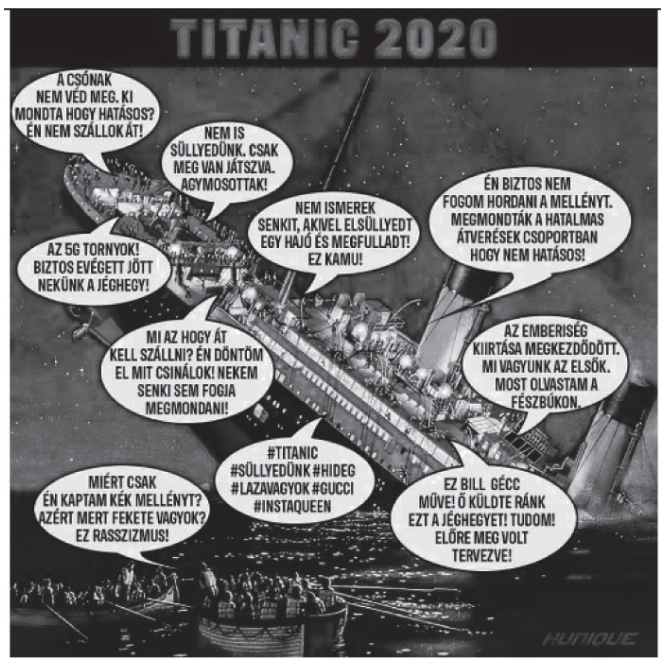

9. ábra. Összefoglaló konteómém 


\section{4. Összegzés}

A 2020-ban kibontakozott, új, korábban nem tapasztalt pandémia globális léptékben is bizonytalan, kiszámíthatatlan egészségügyi, társadalmi, gazdasági helyzetet okozott. Az információs hiánnyal is együtt járó krízishelyzetekben rendszerint megerősödik az alternatív magyarázatok, a konspirációs teóriák jelenléte, mivel az összeesküvés-elméletek a valóságot fekete-fehérre színezik, gyors, egyszerủ és könynyen elérhetőnek tủnő megoldásokat kínálnak a komplex problémákra. Ez a tanulmány a 2020 januárja és szeptembere között, a koronavírus-fertőzéssel kapcsolatban megjelent összeesküvés-elméleteket összegezte, miközben terjedésük, „népszerüségük" magyarázatát a kulturális epidemiológia keretébe helyezte - és kitekintett a koronakonteókra reflektáló, azokat kifigurázó mémekre is.

\section{FORRÁSOK}

(utolsó ellenőrzés minden forrás esetén: 2020. 09. 25.)

BBC News Reality Check team 2020. Coronavirus: The fake health advice you should ignore. $B B C, 2020.03 .08$. https://www.bbc.com/news/world-51735367.

FJ 2020. Iránban hétszáznál többen haltak meg azért, mert metil-alkoholt ittak a koronavírus ellen. Index, 2020. 04. 27. https://index.hu/kulfold/2020/04/27/iran_koronavirus_metilalkohol_mergezes_700_ember_meghalt/.

Hanula Zsolt 2020. Hiába a kormány figyelmeztetése, burjánzanak a koronavírusos álhírek. Index, 2020. 02. 29. https://index.hu/techtud/2020/02/29/hiaba_a_kormany_ figyelmeztetese_burjanzanak_a_koronavirusos_alhirek/.

HVG 2020. Szomorú fordulatot vett az 5G-ellenesek háborúja. $H V G, 2020.05 .11$. https://hvg. hu/tudomany/20200511_5g_halozat_torony_berendezes_szabotazs_rongalas_egyesult_ kiralysag_zaklatas.

Index 2020. Sorra törli a magyar vírustagadók oldalait a Facebook. Index, 2020. 09. 24. https:// index.hu/belfold/2020/09/24/sorra_torli_a_magyar_virustagadok_oldalait_a_facebook/.

Kirkpatrick, Mark é.n. The anti-vaccination movement. Measles and Rubella Initiative. https://measlesrubellainitiative.org/anti-vaccination-movement/.

McKenna, Maryn 2019. The True Dollar Cost of the Anti-Vaccine Movement. Wired, 2019. 03. 26. https://www.wired.com/story/anti-vaccine-movement-true-cost.

Molnár Csaba 2020. Veszélyes ,jótanácsok” terjednek a koronavírusról a Facebookon. Index, 2020. 02. 27. https://index.hu/tech/hoax/2020/02/27/veszelyes_orultseg_terjed_a_ koronavirusrol_a_facebookon._ne_higgyen_neki/.

Portfolio 2020. Már gyújtogatnak és emberekre támadnak a legújabb koronavírusos összeesküvés-elmélet miatt. Portfolio, 2020. 04. 06. https://www.portfolio.hu/uzlet/20200406/ mar-gyujtogatnak-es-emberekre-tamadnak-a-legujabb-koronavirusos-osszeeskuveselmelet-miatt-424400.

Sáringer Viktória 2020. Hamis információk a közösségi oldalakon a koronavírus kapcsán. Közösségi média mindenkinek blog, 2020. 03. 16. https://kozossegi-media-mindenkinek. blog.hu/2020/03/16/s_v_hamis_informaciok_a_kozossegi_oldalakon_a_koronavirus_ kapcsan.

Spring, Marianna 2020. Coronavirus: The seven types of people who start and spread viral misinformation. BBC Trending, 2020. 05. 04. https://www.bbc.com/news/blogs-trending52474347. 
Szicherle Patrik - Krekó Péter 2020. Burjánzanak az álhírek a koronavírus nyomában. PC blog, 2020. 02. 28. https://pcblog.atlatszo.hu/2020/02/28/koronavirus-a-dezinformaciosuniverzumban/.

WHO 2020. Infodemic management: Infodemiology. World Health Organization. https:// www.who.int/teams/risk-communication/infodemic-management https://www.who.int/ docs/default-source/coronaviruse/situation-reports/20200202-sitrep-13-ncov-v3.pdf.

\section{SZAKIRODALOM}

Bakshy, Eytan - Messing, Solomon - Adamic, Lada A. 2015. Exposure to ideologically diverse news and opinion on Facebook. Science 348/6239: 1130-2. http://education.biu. ac.il/files/education/shared/science-2015-bakshy-1130-2.pdf. https://doi.org/10.1126/ science.aaa1160

Blancke, Stefaan - Boudry, Maarten - Braeckman, Johan 2018. Whence pseudoscience? An epidemiological approach. Monograph, Mètode Science Studies Journal 8: 133-9. https:// doi.org/10.7203/metode.8.10007

Blancke, Stefaan - Boudry, Maarten - Pigliucci, Massimo 2017. Why do irrational beliefs mimic science? The cultural evolution of pseudoscience. Theoria 83/1: 78-97. https://doi. org $/ 10.1111 /$ theo. 12109

Boudry, Maarten - Blancke, Stefaan - Pigliucci, Massimo 2015. What makes weird beliefs thrive? The epidemiology of pseudoscience. Philosophical Psychology 28/8: 1177-98. https://doi.org/10.1080/09515089.2014.971946

Boudry, Maarten - Braeckman, J. 2011. Immunizing strategies and epistemic defense mechanisms. Philosophia 39/1: 145-61. https://doi.org/10.1007/s11406-010-9254-9

Boudry, Maarten - Braeckman, J. 2012. How convenient! The epistemic rationale of selfvalidating belief systems. Philosophical Psychology 25/3: 341-64. https://doi.org/10.108 0/09515089.2011.579420

Boyer, Pascal - Barrett, H. Clark 2005. Domain specificity and intuitive ontology. In: Buss, David M. (ed.): The handbook of evolutionary psychology. Wiley, Hoboken, 96-118. https://doi.org/10.1002/9780470939376.ch3

Brennen, J. S. - Simon, F. M. - Howard, P. N. - Nielsen, R. K. 2020. Types, sources, and claims of Covid-19 misinformation. Reuters Institute. https://reutersinstitute.politics. ox.ac.uk/typessources-and-claims-Covid-19-misinformation.

Broniatowski, David A. - Jamison, Amelia M. - Qi, Si Hua - Al Kulaib, Lulwah - Chen, Tao - Benton, Adrian - Quinn, Sandra C. - Dredze, Mark 2018. Weaponized Health Communication: Twitter Bots and Russian Trolls Amplify the Vaccine Debate. Am J Public Health 108/10: 1378-84. https://doi.org/10.2105/AJPH.2018.304567

Buda Béla 1986. A közvetlen emberi kommunikáció szabályszerüségei. Harmadik, bővített kiadás. Animula Kft., Budapest.

Dawkins, Richard 1993. Viruses of the mind. Dennett and his critics: Demystifying Mind. Szerk.: Bo Dahlbom. Blackwell, Cambridge, MA.

Dennett, Daniel C. 1990. Memes and the exploitation of imagination. The Journal of Aesthetics and Art Criticism 48: 127-35. https://doi.org/10.2307/430902

Falyuna Nóra 2017. Az áltudományos szövegek pragmatikai vizsgálata. Esettanulmány a lúgosító diéta példáján. Századvég 84: 85-107.

Falyuna Nóra 2018. Az (ál)tudományos ismeretek és az internet. Jel-Kép 4: 35-50. https://doi. org/10.20520/JEL-KEP.2018.4.35

Fehér Katalin - Király Olívia 2017. Álhíresülés - a hamis hírek dinamikája a médiában. Századvég 84: 39-49. 
Fehér Katalin 2016. Digitalizáció és új média. Trendek, stratégiák, illusztrációk. Akadémiai Kiadó, Budapest. https://doi.org/10.1556/9789630597432

Flaherty, Dennis K. 2011. The vaccine-autism connection: a public health crisis caused by unethical medical practices and fraudulent science. The Annals of Pharmacotherapy 45/10: 1302-4. https://doi.org/10.1345/aph.1Q318

Gelfert, Axel 2018. Fake News: A Definition. Informal Logic 38/1: 84-117. https://doi. org/10.22329/il.v38i1.5068

Jun, Youjung - Menga, Rachel - Johar, Gita Venkataramani 2017. Perceived social presence reduces fact-checking. PNAS 114/23: 5976-5981. http://www.pnas.org/content/ early/2017/05/16/1700175114.full. https://doi.org/10.1073/pnas.1700175114

Kuiper, N. A. - Martin, R. A. - Olinger, L. J. 1993. Coping humor, stress, and cognitive appraisals. Canadian Journal of Behavioural Science 25/1: 81-96. https://doi.org/10.1037/ h0078791

Martin, Rod A. 2007. The psychology of humor: An integrative approach. Elsevier Academic Press, Burlington, MA.

Mulkay, M. 1988. On humor: Its nature and its place in modern society. Basil Blackwell, New York.

Pariser, Eli 2011. The filter bubble: What the Internet is hiding from you. Penguin Press, New York.

Rizeq, Jala - Flora, David B. - Toplak, Maggie E. 2020. An examination of the underlying dimensional structure of three domains of contaminated mindware: paranormal beliefs, conspiracy beliefs, and anti-science attitudes. Thinking - Reasoning. https://doi.org/10.1 080/13546783.2020.1759688.

Sperber, Dan - Clement, Fabrice - Heintz, Christophe - Mascaro, Olivier - Mercier, Hugo Origgi, Gloria - Wilson, D. 2010. Epistemic vigilance. Mind - Language 25/4: 359-93. https://doi.org/10.1111/j.1468-0017.2010.01394.x

Sperber, Dan 1996. Explaining culture. A naturalistic approach. Blackwell, Oxford.

Stanovich, K. E. 2009. What intelligence tests miss: The psychology of rational thought. Yale University Press.

Stanovich, K. E. 2016. The comprehensive assessment of rational thinking. Educational Psychologist 51/1: 23-34. https://doi.org/10.1080/00461520.2015.1125787

Stanovich, K. E. - Toplak, M. E. - West, R. F. 2008. The development of rational thought: A taxonomy of heuristics and biases. Advances in Child Development and Behavior 36: 251-85. https://doi.org/10.1016/S0065-2407(08)00006-2

Stanovich, K. E. - West, R. F. - Toplak, M. E. 2016. The rationality quotient: Toward a test of rational thinking. MIT Press. https://doi.org/10.7551/mitpress/9780262034845.001.0001

Sutton, R. M. - Douglas, K. M. 2014. Examining the monological nature of conspiracy theories. In: Power, politics, and paranoia: Why people are suspicious of their leaders. Cambridge University Press. 254-72. https://doi.org/10.1017/CBO9781139565417.018

Szvetelszky Zsuzsanna 2017. Közösségi kételyek. Századvég 84: 27-37.

Tanács János 2016. Az összeesküvés-elméletek fogságában. Kézirat.

Veszelszki Ágnes - Falyuna Nóra 2019. Az áltudományosság leleplezése érveléstechnikainyelvészeti eszközökkel. Médiakutató 2019/3: 39-51.

Veszelszki Ágnes - Falyuna Nóra 2020. Kommunikációs és médiatudatosság az áltudományos nézetek feltárásában. In: H. Varga Gyula (szerk.): Személyközi és médiakommunikációs tudatosság az iskolában. Hungarovox Kiadó, Budapest, 131-44.

Veszelszki Ágnes 2013. Humor a digitális kommunikációban: az internetes mémek. In: Vargha Katalin, T. Litovkina Anna, Barta Zsuzsanna (szerk.): Sokszinü humor. A III. Magyar Interdiszciplináris Humorkonferencia elöadásai. Tinta Könyvkiadó - ELTE Bölcsészettudományi Kar - Magyar Szemiotikai Társaság, Budapest, 11-25. 
Veszelszki Ágnes 2017. Az álhírek extra- és intralingvális jellemzői. Századvég 84: 51-82. Veszelszki Ágnes 2020a. Karanténszótár. Virális tartalom. IKU, Budapest.

Veszelszki Ágnes 2020b. Kórlenyomat és korlenyomat - új szavakkal kifejezve. E-nyelv Magazin, 2020. 04. 16.

Veszelszki Ágnes 2020c. „A komment teszi fel rá a koronát”. Humor és mémek a koronavírus idején. E-nyelv Magazin 2020/2, 2020. 05. 18.

Veszelszki Ágnes 2021. Felhasználók az álhírek fogságában. In: Mernyei Ákos - Orbán Balázs (szerk.): Magyarország 2020. 50 tanulmány az elmúlt 10 évröl. Mathias Corvinus Collegium, Budapest. 1005-21.

Viḳe-Freiberga, Vaira - Däubler-Gmelin, Herta - Hammersley, Ben - Pessoa Maduro, Luís Miguel Poiares 2013. A free and pluralistic media to sustain European democracy. The Report of the High Level Group on Media Freedom and Pluralism. Charter of Fundamental Rights of the European Union, Article 11.2. https://ec.europa.eu/digital-single-market/ sites/digital-agenda/files/HLG\%20Final\%20Report.pdf.

Vraga, Emily K. - Tully, Melissa - Bode, Leticia 2020. Empowering Users to Respond to Misinformation about Covid-19. Media and Communication 8/2: 475-9. https://doi. org/10.17645/mac.v8i2.3200

Zimmer, Franziska-Scheibe, Katrin-Schmoly, Lorenz-Dreisiebner, Stefan 2019. Fake News im Zeitalter der Social Media. In: Büttner, Stephan (Hrsg.): Die digitale Transformation in Institutionen des kulturellen Gedächtnisses. Antworten aus der Informationswissenschaft. Simon Verlag für Bibliothekswissen, Berlin, 211-39.

Zuiderveen Borgesius, Frederik J. - Trilling, Damian - Möller, Judith - Bodó, Balázs - de Vreese, Claes H. - Helberger, Natali 2016. Should we worry about filter bubbles? Internet Policy Review 5/1. https://doi.org/10.14763/2016.1.401

\section{MELLÉKLET ${ }^{3}$}

1. Komment a tájékoztatás hiányával kapcsolatban (forrás: Facebook, ismeretlen felhasználó, 2020. 02. 29.)

Az Index most megint úgy mondta meg a tutit, hogy azzal kábé semmire sem megyünk. Pontról pontra cáfolták a napok óta futótüzként terjedő szöveget, melyben állítólag egy « olasz orvos » magyarázza el, mit is kéne tudni a koronavírusról : hogyan terjed, mire kell vigyázni és mik volnának a fertőzés, illetve megbetegedés fázisai. Egy aprócska dologról megfeledkezik az Index über-tájékozott szakértője : hogy az emberek vajon miért kezdték el terjeszteni az első útjukba kerülő gyakorlatias útmutatót. Segítek : nem azért, mert mind hiszékeny hülyék volnának, hanem mert A MAI NAPIG SENKITŐL SEM LEHET RÖVID ÉS GYAKORLATIAS ÚTMUTATÓT KAPNI, HOGY MÉGIS MI A FENÉT TEHETNE AZ EMBER, HOGY NE FERTÖZÖDJÖN MEG VAGY MIK A TÜNETEK, STB. Se a hatóságok, se senki nem áll elő semmi használható, rövid leírással, aminek tényleg gyakorlati hasznát lehetne venni. Mindenféle megfoghatatlan részinformációkat adnak, meg kábé annyit, hogy mossunk kezet stb. Köszi. Közben megy tovább a kincstári hablaty, hogy mifelénk egyelöre minden nagyon oké, nem tudnak fertőzöttről stb. stb. - de talán már nincs élö ember, aki ebben vakon bízni tudna. Vagy tényleg csak nagyon vakon...

Csak egy példa a használhatatlan infókra : először olyanokat írtak, hogy denevérböl került át emberbe, majd a tobzoska került gyanúba, de öszintén ki a fészkes fenét érdekelnek ilyen típusú információk egy konkrét járványveszélynél. Egyébként félig már beismerték

3 A szövegeket eredeti írásmóddal, javítás és módosítás nélkül közöljük. 
a kínai hatóságok, hogy a vuhani víruslaborból kerülhetett ki eredetileg a vírus, ami úgy 300 méterre van attól az ominózus állatpiactól... A híradások 99 \%-a különböző (folyton változó) véleményekből és kétes statisztikákból áll a járvány terjedéséről - amivel mi halandó emberek konkrétan semmit sem tudunk kezdeni. Gyakorlati útmutatást alig lehet kiszürni ebből a katyvaszból, amit a professzionális újságírás és a nyilván nem kevésbé profi virológia képes volt megfogalmazni a témában.

Közben az emberek kábé minden országban fokozatosan mennek végig azokon a KüblerRoss stádiumokon, amivel a halálosnak vélt betegséggel való szembesülés stádiumait szokták jellemezni : 1. Tagadás 2. Düh, harag 3. Alkudozás 4. Depresszió 5. Elfogadás (ez utóbbiba nagyon kevesen jutnak még el).

Emlékszünk még ? Én még emlékszem, mikor egy hónapja még rémhírterjesztő idiótának számítottam azzal, hogy valós veszélyekről beszéltem.

Akik már elkezdtek tartós élelmiszereket és fertőtlenítőt bevásárolni, azok az alkudozásig már minimum eljutottak, de inkább már a depresszió felé tartanak. Illetve reálisan látják a veszélyeket. Reálisabban mint ahogy a média és a hatóságok egyelöre tájékoztatnak a vírusról.

2. Egy koronavírus-konteó leírása (forrás: Facebook, ismeretlen felhasználó, 2020. 03. 13.)

Ma este olvastam egy érdekességet, amelytől gyakorlatilag...leesett az állam!

Amikor Amerika - élén Donald Trumppal - embargózta Kínát, és az egyik mobiltelefongyártó cég Android aplikációt szabotálta, akkor valamit kitaláltak adott kínai gazdasági érdekkörök. Elegük lett.

Csak azt sajnálom, hogy mi, a világ nagy alakulásában - jelentéktelen emberi életek vagyunk más, tehetősebb és befolyásosabb emberek szemében...Rögvest összeszorul a szívem ha csak erre gondolok.

Szóval lehet, hogy maguk a kínaiak idították el ezt a mára világméretüre duzzadt virus hisztit, mivelhogy a többi „hétköznapi” vírusos megbetegedéstől ámbár többen meghalnak naponta, de jelen esetben felhasználták a média adta tornadót, amely ennyire felfújta a híreket, és ennyire betelepedett az emberi elmékbe a félelem, és a „félsz" érzet. Tegnap be is mondtak egy nagy érdekességet a kínai gazdaságot mozagtó emberek, pezsgőspohárral. Az elmúlt napokban Kína hatalmas rekordot döntött, amely mentén a saját országában befektetett nyugati társaságok részvényeinek mintegy 30-55\% -át megvásárolta, így rengeteg más állami érdekeltséget mutató multicégnél többségi tulajdonos lett. Inkább felvásárolta „bagóért” a konkurenciát - mintsem megvásárolta volna azt tisztességesen (lehet, hogy sok esetben nem is kapott volna 1 részvényt sem), emberi életeket nem veszélyeztetve ebben a manőverben. Ha ez igaz, akkor ez a kommunista ország egy piszkosúl remek játékot játszott az egész világ előtt, és felülmúlta az európaiakat, és az okos amerikai demokratákat is. A dominót bepüccintették, a hatás elindult, mindenki (egyének, közösségek, állam stb.) beáll a sorba, de részükről a történet teljesen másról szól.

A wuhani helyzet miatt a kínai valuta, a jüan csökkenni kezdett, ám a Kínai Központi Bank nem tett lépéseket a fejlemények megállítására. Nem kompenzált, csak állt, és nem tett semmit.

Emlékeztek, hogy sok pletyka is szólt arról, hogy Kínának pénzügyi gondjai lehetnek még ebből, valamint az is, hogy még elegendő maszkja sem volt a koronavírus elleni küzdelemhez - így a „fejlet” Kína nagy gazdasági gondba ütközött. Stb.

Ezek a pletykák a világsajtóban meglebegtetve, és Xi Jinping kijelentése, hogy kész bármi áron megvédeni Wuhan lakosait a határok blokkolásával - a részvényárak (44-60\%) hirtelen csökkenéséhez vezettek a kínai technológiai, vegyipari, és nehéziparban. A külföldi cégek, és a pénzügyi cápák elkezdték eladni az összes kínai részvényeiket, de a vásárlói oldalon (akik eladásra kiáltották, nem érdekelte őket, hogy ki vezsi meg - csak vigye, vegye) senki sem 
akarta megvenni őket, amíg teljesen le nem értékelödnek. Hiszen egy összeomló Kína - ugyebár nem ér sokat. Meg amúgy is... Kínának befellegzett.

Xi Jinping „,mesterlépést” tett, amely mentén egy egész hétig várt (mindeközben 3 napja nem volt Kínában vírusos megbetegedés, szóval pont ennyi ideje rendezték el a modern korunk legnagyobb tőzsdemanipulációját, és már nincs szükségük a gerjesztett médiára), az egyik sajtótájékoztatókon bombaszám érkező kérdésekre csak símán elmosolyodott (mintha semmi különös nem történt volna), és amikor az ár a „megengedett” határ alá esett, minden részvényt megvásárolt Kína. Az európaiaktól és az amerikaiaktól - egyszerre!

Amire többen a kérdőjeleikből felébredtek, akkor jöttek rá, hogy már késő, mert az öszszes részvény Kína kezébe került. Temérdek ismert világmárkának a kínai telepgyárai, termelési pontjai, adot szakaszoknak Kínában kiépített telepei stb., stb. lettek egycsapásra kínai felügyelet alatt. Kína nemcsak nyert, hanem a többségi részvényese lett az európaiak és az amerikaiak által oda épített vállalatoknak. Így váltak a kínaiak további iparágaknak a többségi tulajdonosaivá, amelytől az EU és Amerika függ. Tehát a jövőben az árat, a brandeket, az irányokat a Kínai Kommunista Párt fogja meghatározni. A háttérhatalom.

Sakk-Matt!

\author{
Veszelszki Ágnes \\ tanszékvezetô egyetemi docens \\ Budapesti Corvinus Egyetem Kommunikáció és Szociológia \\ Intézet Kommunikáció- és Médiatudomány Tanszék \\ http://orcid.org/0000-0003-2226-0607
}

\title{
SUMMARY \\ Contagious conspiracy theories: Coronavirus theories as memes
}

\author{
Veszelszki, Ágnes
}

Conspiracy theories attribute a series of events, whether they are interrelated or otherwise, to some malignant activity of usually influential people. Such theories are actually irrefutable since they treat evidence supporting and undermining their arguments in an asymmetrical manner: they accept supporting evidence without further ado but they claim that contrary pieces of evidence are misleading, deceptive, or even unscientific. Cultural epidemiology accounts for their widespread acceptance by three reasons: first, their intuitive appeal (claims that fulfil our intuitive, non-conscious, automatic and spontaneous expectations have the most chance of becoming popular); second, the mimicry of scientific statements (they appear to employ scientific methods, language, and system of institutions), and third, their immunity to criticism (they defy any empirical evidence). The paper studies conspiracy theories that spread in the online media with respect to the coronavirus pandemic of 2019-2020 in two respects: it analyses such theories as memes, treating the latter as units of cultural epidemiology, and then it presents a selection of internet memes from 2020 that treat conspiracy theories in a critical perspective.

Keywords: conspiracy theory, memetics, internet meme, pseudoscience, coronavirus pandemic 